\title{
In Vitro Effects of Bromoalkyl Phenytoin Derivatives on Regulated Death, Cell Cycle and Ultrastructure of Leukemia Cells
}

\author{
KATARZYNA ŚLADOWSKA ${ }^{1}$, MAŁGORZATA OPYDO-CHANEK ${ }^{1}$, TEODORA KRÓL ${ }^{2}$, \\ WOJCIECH TRYBUS ${ }^{2}$, EWA TRYBUS ${ }^{2}$, ANNA KOPACZ-BEDNARSKA ${ }^{2}$, \\ JADWIGA HANDZLIK ${ }^{3}$, KATARZYNA KIEĆ-KONONOWICZ ${ }^{3}$ and LIDIA MAZUR ${ }^{1}$ \\ ${ }^{1}$ Department of Experimental Hematology, Jagiellonian University, Krakow, Poland; \\ ${ }^{2}$ Department of Cell Biology and Electron Microscopy, The Jan Kochanowski University, Kielce, Poland; \\ ${ }^{3}$ Department of Technology and Biotechnology of Drugs, Medical College, Jagiellonian University, Krakow, Poland
}

\begin{abstract}
Background/Aim: To search for new antileukemic agents, the chemical structure of phenytoin was modified. A possible cytotoxic activity of three bromoalkyl phenytoin analogs, methyl 2-(1-(3-bromopropyl)-2,4-dioxo-5,5diphenylimidazolidin-3-yl) propanoate (PH2), 1-(3bromopropyl)-3-methyl-5,5-diphenylimidazolidine-2,4dione (PH3) and 1-(4-bromobutyl)-3-methyl-5,5diphenylimidazolidine-2,4-dione ( $\mathrm{PH} 4)$ on regulated cell death, the cell cycle and cell ultrastructure was assessed. Materials and Methods: The experiments were performed in vitro on HL-60 and U937 cells, using flow cytometry and electron microscopy methods. Results: Application of PH2, $\mathrm{PH}$, and PH4 resulted in cell surface exposure of phosphatidylserine and plasma membrane impairment, caspase-8, -9, and -3/7 activation, dissipation of mitochondrial membrane potential, DNA breakage, cell-cycle disturbance and cell ultrastructural changes. In general, $\mathrm{PH} 3$ appeared to be the most active against the leukemia cells, and all bromoalkyl hydantoins, PH2-PH4, were more active in HL-60 cells than in U937 cells. Conclusion: The antileukemic activity of the bromoalkyl phenytoin analogs depended on the combination of $N$-hydantoin substituents and the human cell line used.
\end{abstract}

Phenytoin molecule (5,5-diphenylhydantoin, 5,5-diphenylimidazolidine-2,4-dione) is known as an anticonvulsant and

Correspondence to: Lidia Mazur, Ph.D., D.Sc., Department of Experimental Hematology, Institute of Zoology and Biomedical Research, Jagiellonian University in Krakow, Gronostajowa 9, PL 30-387 Krakow, Poland. Tel: +48 126645237, Fax: +48 126645101, e-mail: lidia.mazur@uj.edu.pl

Key Words: Bromoalkyl phenytoin derivatives, human leukemia cells, regulated cell death, cell cycle, cell ultrastructure. antiarrhythmic drug $(1,2)$ but it is also an interesting structure for chemical modifications to obtain new biologically-active compounds that act on therapeutically important proteins, e.g. serotonin- (3) or adrenergic (4) receptors as well as on multidrug resistance (MDR) proteins in bacteria $(5,6)$ and cancer cells $(7,8)$. Due to the structural similarity to the known non-steroidal antiandrogen nilutamide (5,5-dimethyl-3-(4-nitro3-(trifluoromethyl)phenyl) hydantoin) used in therapy of prostate cancer (9), phenytoin seems to be also an interesting starting point in search for new anticancer agents. Nevertheless, available information on their cytotoxic action on pathological cells is scarce $(7,8,10-12)$.

Recently, phenytoin derivatives with or without alkyl chain at the position 1 of hydantoin and methyl or ester substituent at the position 3, including methyl 2-(2,4-dioxo-5,5diphenylimidazolidin-3-yl)propanoate (PH1), methyl 2-(1-(3bromopropyl)-2,4-dioxo-5,5-diphenylimidazolidin-3yl)propanoate (PH2), 1-(3-bromopropyl)-3-methyl-5,5diphenylimidazolidine-2,4-dione (PH3) and 1-(4-bromobutyl)3-methyl-5,5-diphenylimidazolidine-2,4-dione (PH4), were synthesized. Their structures were elected as probably cytotoxic in pathological cells based on the toxicology training in silico, and using OSIRIS bioinformatics tools (http://www.organic-chemistry.org/prog/ peo/). The results of previous in vitro studies confirmed this hypothesis, showing that $\mathrm{PH} 1, \mathrm{PH} 2, \mathrm{PH} 3$, and $\mathrm{PH} 4$ affected leukemia cells viability, volume and count (13). Among these four agents, the phenytoin derivative PH1 without bromoalkyl substituent appeared to be less active against leukemia cells than the bromoalkyl phenytoin analogs, PH2, PH3 and PH4 (Figure 1).

To our knowledge, there are no published data on triggering regulated cell death (14) and causing changes in cell cycle and cell ultrastructure by the bromoalkyl phenytoin analogs, $\mathrm{PH} 2$, $\mathrm{PH} 3$, and PH4. Therefore, understanding the mechanisms of action of these 5,5-diphenylhydantoin derivatives against 

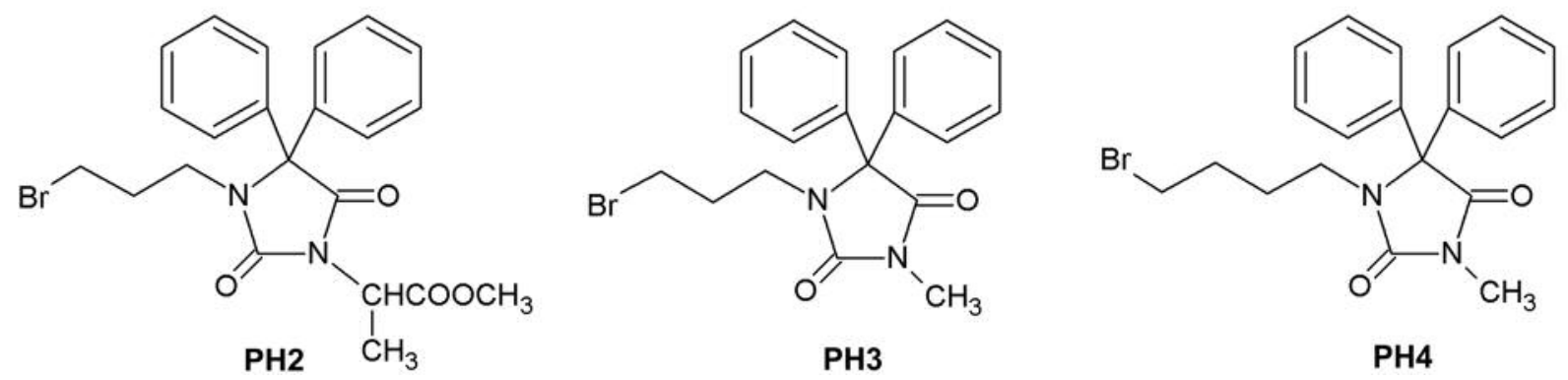

Figure 1. Chemical structures of three bromoalkyl phenytoin derivatives, PH2, PH3, and PH4.

pathological cells is of great importance in determining their anticancer potential.

The aim of the present study was to assess and compare the in vitro antileukemic activity of $\mathrm{PH} 2, \mathrm{PH} 3$ and $\mathrm{PH} 4$. To determine the mechanisms of their action on human leukemia cells, their influence on plasma membrane diversity and integrity, caspase activation, mitochondrial membrane potential, DNA damage, the cell cycle and cell ultrastructure, was analyzed.

\section{Materials and Methods}

Cells. The experiments were carried out on human promyelocytic leukemia HL-60 and human histiocytic lymphoma U937 cells obtained from American Type Culture Collection (Rockville, MD, USA). The cells were maintained in RPMI 1640 medium (Gibco BRL Life Technologies, Waltham, MA, USA) supplemented with $10 \%$ fetal calf serum (Gibco BRL Life Technologies, Waltham, MA, USA), $2 \mathrm{mM}$ L-glutamine (Sigma Aldrich, St. Louis, MO, USA) and antibiotic antimycotic solution (Sigma Aldrich, St. Louis, MO, USA) containing 20 units of penicylin, $20 \mu \mathrm{g}$ streptomycin and $0.05 \mu \mathrm{g}$ amphotericin B. HL-60 and U937 cells were grown at $37^{\circ} \mathrm{C}$ in a humidified atmosphere of $95 \%$ air and $5 \% \mathrm{CO}_{2}$ (HERAcell incubator, KendroLab, Warsaw, Poland). The cells were passaged every third day and periodically tested for Mycoplasma infection.

Chemicals. The bromoalkyl phenytoin derivatives (Figure 1), methyl 2-(1-(3-bromopropyl)-2,4-dioxo-5,5-diphenylimidazolidin-3-yl) propanoate (PH2), 1-(3-bromopropyl)-3-methyl-5,5-diphenylimidazolidine-2,4-dione (PH3) and 1-(4-bromobutyl)-3-methyl-5,5diphenylimidazolidine-2,4-dione (PH4) were obtained from Department of Technology and Biotechnology of Drugs (Jagiellonian University in Krakow, Poland) using methods previously described (5). Purity and identity of these compounds were confirmed, using thin layer chromatography (TLC), spectral methods ( ${ }^{1} \mathrm{H}-\mathrm{NMR}$ and IR), elemental analysis and melting point measurements. The tested bromoalkyl phenytoin derivatives were dissolved in dimethyl sulfoxide (DMSO, Sigma Aldrich, St. Louis, MO, USA) and all solutions were freshly prepared before treatment of HL-60 and U937 cells.

Agents concentration and cell treatment. After diluting the cell suspension to a density of $1.5 \times 10^{5}$ cells $/ \mathrm{ml}$ of the complete RPMI 1640 medium, HL-60 and U937 cells were exposed to the action of the bromoalkyl phenytoin analogs, $\mathrm{PH} 2, \mathrm{PH} 3$, and $\mathrm{PH} 4$, at the concentrations of $50 \mu \mathrm{M}$ and $100 \mu \mathrm{M}$, which were chosen based on the results of a previous study (6). The control material consisted of untreated HL-60 and U937 cells and those treated only with $0.4 \%$ DMSO.

Flow cytometric annexin V-FITC/PI assay. The cell surface exposure of phosphatidylserine and plasma membrane impairment were assessed by dual staining of leukemia cells with fluoresceinated annexin V (annexin V-FITC) and propidium iodide (PI), using Annexin V-FITC Apoptosis Detection Kit (Becton Dickinson Pharmingen $^{\mathrm{TM}}$, Vienna, Austria). Briefly, the leukemia cell suspension was centrifuged for $7 \mathrm{~min}$ at $100 \times g$ and $4^{\circ} \mathrm{C}$, the supernatant was removed by aspiration, and the cells were washed in $1 \mathrm{ml}$ of phosphate buffered saline (PBS, BioMed, Lublin, Poland). After the washing step, the cell pellet was resuspended in $100 \mu \mathrm{l}$ of binding buffer. Then $2.5 \mu \mathrm{l}$ of annexin V-FITC and $2.5 \mu \mathrm{l}$ of PI solution were added and the cells were incubated in the dark for $15 \mathrm{~min}$ at room temperature. Following incubation, $400 \mu \mathrm{l}$ of binding buffer was added into each cell sample which was placed on ice, away from light. FITC and PI fluorescence was measured by flow cytometry (Becton Dickinson, San Jose, CA, USA).

Flow cytometric CaspGLOW Red Active Caspase assays. The leukemia cells with active caspase- 8 and caspase- 9 were detected, using respectively, CaspGLOW Red Active Caspase-8 Staining Kit and CaspGLOW Red Active Caspase-9 Staining Kit (Biovision, Milpiats, CA, USA). The cell suspension was centrifuged for $7 \mathrm{~min}$ at $100 \times g$ and $37^{\circ} \mathrm{C}$, and the supernatant was removed by aspiration. The cell pellet was resuspended in $150 \mu$ of PBS, $0.5 \mu$ of Red-IETDFMK or $0.5 \mu$ of Red-LEHD-FMK was added into each sample and the cells were incubated for $1 \mathrm{~h}$ at $37^{\circ} \mathrm{C}$. Then the cells were centrifuged, the supernatant was removed and the cells were washed twice in $500 \mu \mathrm{l}$ of wash buffer. After the washing step, the cells were resuspended in $300 \mu$ of wash buffer and the cell samples were immediately analyzed, using flow cytometry (Becton Dickinson, San Jose, CA, USA).

Flow cytometric CellEvent ${ }^{T M}$ Caspase Green assay. The leukemia cells with active caspase-3/7 were identified using CellEvent ${ }^{\mathrm{TM}}$ Caspase-3/7 Green Flow Cytometry Assay Kit (Molecular Probes, Eugene, OR, USA). The cell suspension was centrifuged for $7 \mathrm{~min}$ at $100 \times g$ and $37^{\circ} \mathrm{C}$, and the supernatant was removed by aspiration. The cell pellet was resuspended in $500 \mu \mathrm{l}$ of PBS. Then $0.5 \mu \mathrm{l}$ of CellEvent ${ }^{\mathrm{TM}}$ Caspase-3/7 Green Detection reagent was added into each 
A g
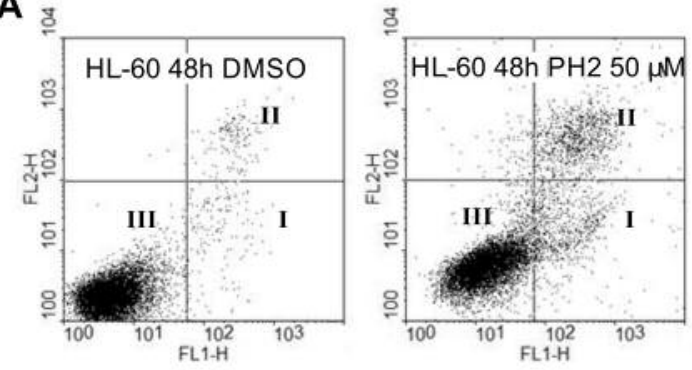

C

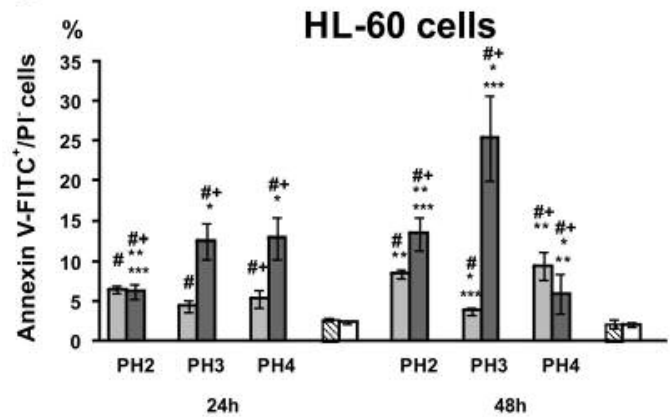

E

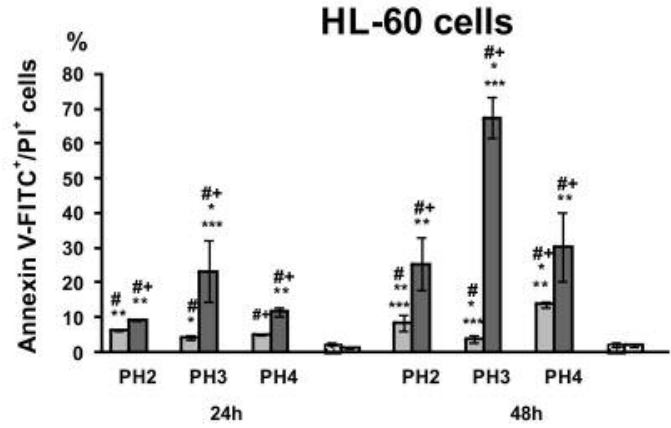

$B_{\text {g }}$
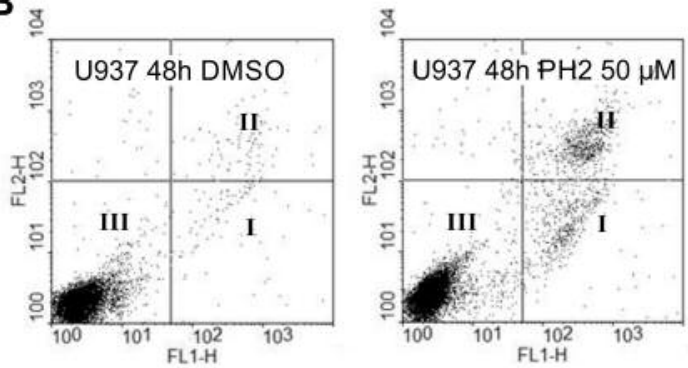

D

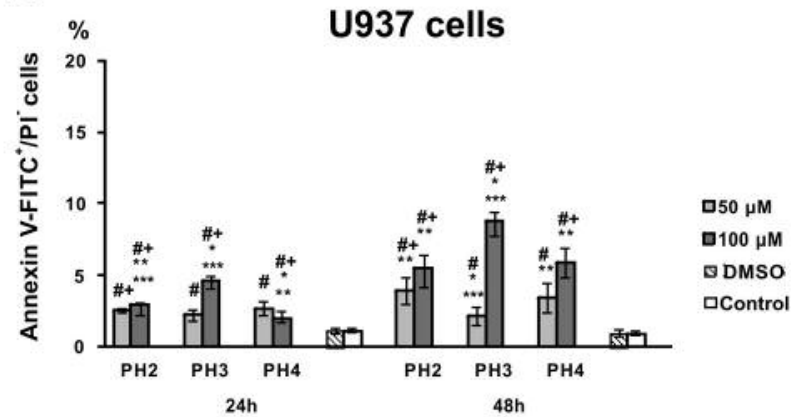

$\mathbf{F}$

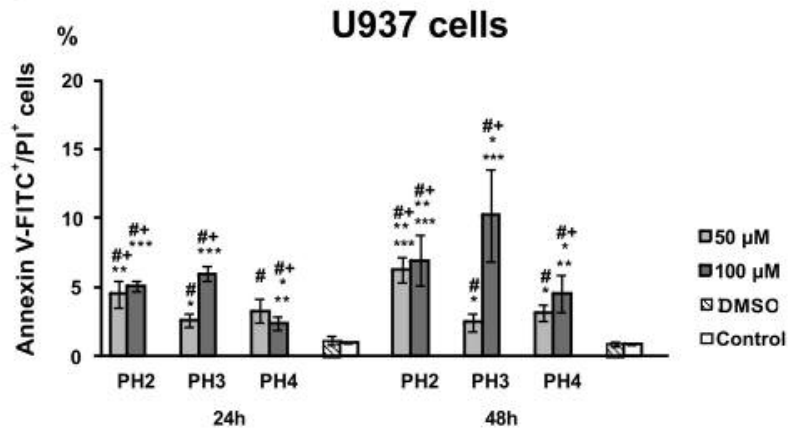

Figure 2. Effects of the bromoalkyl phenytoin derivatives, $\mathrm{PH} 2, \mathrm{PH}$, and $\mathrm{PH} 4$, on phosphatidylserine externalization and plasma membrane impairment in HL-60 and U937 cells. Representative dot plots for HL-60 (A) and U937 (B) cells obtained 48 h after application of DMSO only, and PH2; FL1-H - green fluorescence of FITC; FL2-H - red fluorescence of PI. I - early apoptotic cells with phosphatidylserine externalization (annexin $V$-FITC ${ }^{+} / P I^{-}$); II - late apoptotic and necrotic cells with phosphatidylserine externalization and plasma membrane impairment (annexin $V$-FITC $\left.{ }^{+} / P I^{+}\right) ; I I I$ - live cells (annexin V-FITC $/ P I^{-}$). The frequency of annexin $V$-FITC ${ }^{+} / P^{-}(C, D)$, annexin $V$-FITC ${ }^{+} / P I^{+}(E, F) H L-60(C, E)$ and $U 937(D, F)$ cells observed $24 \mathrm{~h}$ and $48 \mathrm{~h}$ after their exposure to the action of the tested phenytoin analogs. Values significantly different at $p<0.05$ according to the Tukey's multiple range test: *, **,*** between the groups of leukemia cells treated with the phenytoin derivatives, \# compared to controls; + between the time points.

sample, and the cells were incubated for $30 \mathrm{~min}$ at $37^{\circ} \mathrm{C}$. After incubation, the cells were analyzed by flow cytometry (Becton Dickinson, San Jose, CA, USA).

Flow cytometric TMRE test. Mitochondrial membrane potential was determined using TMRE (tetramethylrhodamine ethyl ester perchlorate) assay. A TMRE stock solution was prepared at a concentration of $10 \mathrm{mM}$ in DMSO and stored at $-20^{\circ} \mathrm{C}$. The final concentration of TMRE staining solution used was $100 \mathrm{nM}$. The leukemia cell suspensions, containing approximately $2.5-5 \times 10^{5}$ cells $/ \mathrm{ml}$, were centrifuged for $7 \mathrm{~min}$, at $100 \times g$ and $37^{\circ} \mathrm{C}$ (MPW351RH, Med. Instruments, Warszawa, Poland). Then the cell pellet was washed twice in $1 \mathrm{ml}$ of warm Hank's balanced salt solution
(HBSS, Gibco BRL Life Technologies, Waltham, MA, USA). Next, the cells were resuspended in $100 \mu \mathrm{l}$ of $100 \mathrm{nM}$ TMRE, and incubated at $37^{\circ} \mathrm{C}$ in the darkness. After $20 \mathrm{~min}$ incubation, the cells were washed with $1 \mathrm{ml}$ of warm HBSS and centrifuged. Next, the supernatant was discarded, the cells were resuspended in $500 \mu \mathrm{l}$ of HBSS, and TMRE fluorescence was immediately detected by flow cytometry (Becton Dickinson, San Jose, CA, USA).

Flow cytometric APO-BrdU assay. The two-colour staining method for labelling DNA breaks and total cellular DNA was performed, using APO-BrdU Kit (Becton Dickinson Pharmingen ${ }^{\mathrm{TM}}$, Vienna, Austria). Briefly, the leukemia cells were fixed in $1 \%$ formaldehyde (Polish Chemical Reagents, S.A., Gliwice, Poland) in PBS, kept in a fridge 
A
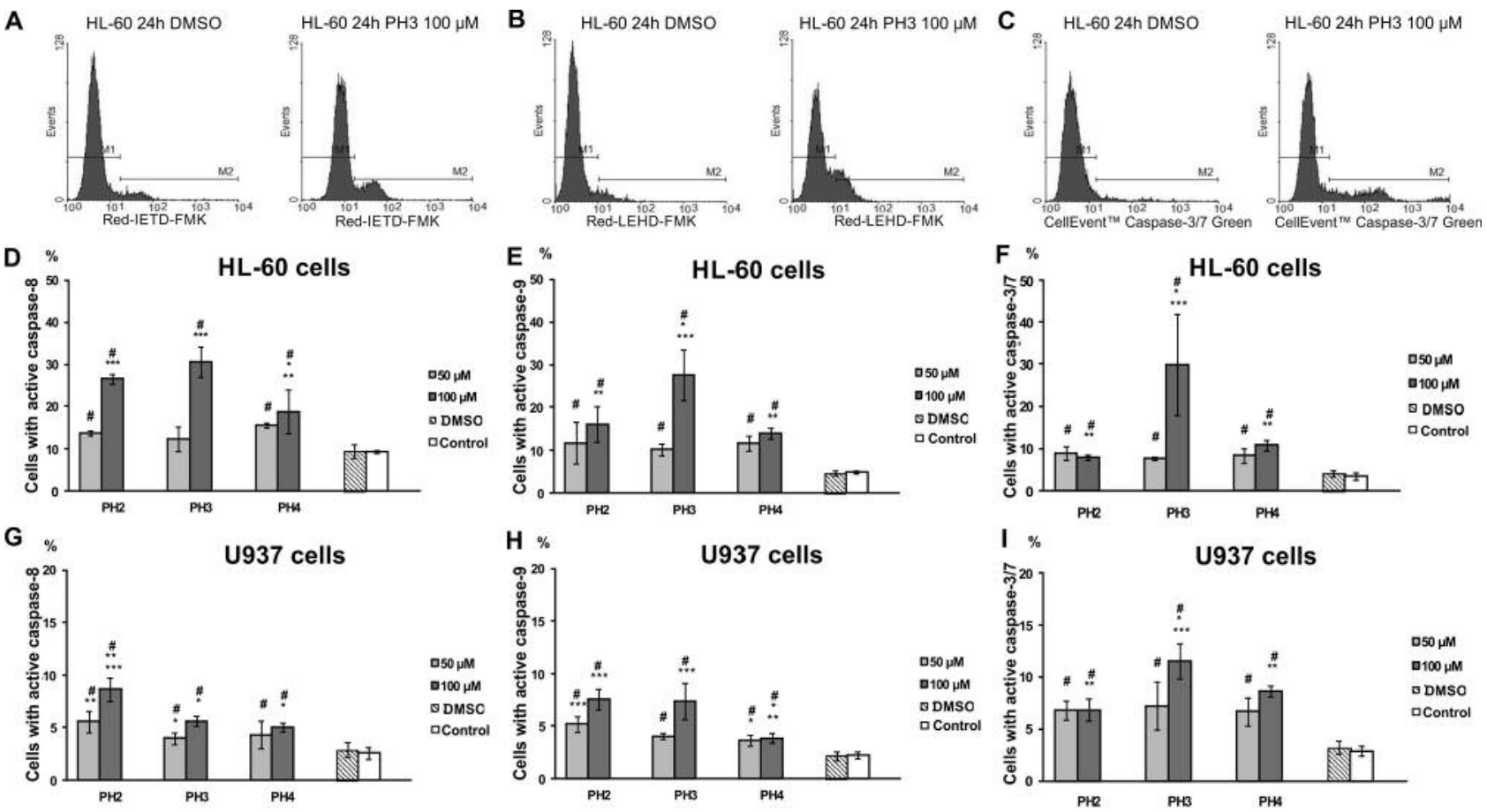

Figure 3. Effects of the bromoalkyl phenytoin derivatives, PH2, PH3, and PH4, on activation of caspase-8, -9 and $-3 / 7$ in HL-60 and U937 cells. Representative histograms of HL-60 cells $(A, B, C)$, obtained 24 h after application of DMSO only, and PH3; $X$ axis: (A) fluorescence of Red-IETDFMK, a caspase-8 inhibitor IETD-FMK conjugated to sulfo-rhodamine; (B) - fluorescence of Red-LEHD-FMK, a caspase-9 inhibitor LEHD-FMK conjugated to sulfo-rhodamine, $(C)$ - fluorescence of CellEvent ${ }^{T M}$ Caspase-3/7 Green Detection Reagent, a fluorogenic substrate for activated caspases-3/7. M1 - HL-60 cells without active caspase-8 (A), -9 (B) and -3/7 (C); M2 - cells with active caspase-8 (A), -9 (B) and -3/7 (C); The frequency of $H L-60(D, E, F)$ and $U 937(G, H, I)$ cells with active caspase-8, -9 and $-3 / 7$ observed $24 \mathrm{~h}$ after after their exposure to the action of the tested phenytoin analogs. Values significantly different at $p<0.05$ according to the Tukey's multiple range test: *,**, *** between the groups of leukemia cells treated with PH2, PH3, and PH4, \# compared to controls.

for $30 \mathrm{~min}$, and then stored at $-20^{\circ} \mathrm{C}$ in $80 \%$ ethanol until analysis. The leukemia cell suspension was centrifuged for $7 \mathrm{~min}$ at $100 \times g$ and $80 \%$ ethanol was removed by aspiration. Next, the TUNEL method was performed according to the APO-BrdU protocol described in detail by Mazur et al. (15). Finally, $300 \mu \mathrm{l}$ of the PI/RNase solution was added to the tube containing $100 \mu \mathrm{l}$ of the antibody solution, and the cells were incubated in the dark for $30 \mathrm{~min}$ at room temperature. The fluorescence of both FITC conjugated with anti-BrdU and PI was detected by flow cytometry (Becton Dickinson, San Jose, CA, USA).

Electron microscopic analysis of cells. The fixation, contrasting and immersion of HL-60 cells for electron microscopy were performed according to the modified method described by Marzella and Glauman (16). Briefly, leukemia cells were fixed in $3 \%$ glutaraldehyde (Serva, Heidelberg, Germany) in $0.1 \mathrm{M}$ cacodylate buffer, fixed and postfixed in osmium tetroxide (SPI Supplies, West Chester, PA, USA), dehydrated in increasing series of ethanol (10-99.9 \%, Chempur, Piekary Śląskie, Poland). After dehydratation the cells were placed in a mixture of alcohol with propylene oxide (Sigma Aldrich, St. Louis, MO, USA), respectively, in a ratio of $3: 1,1: 1,1: 3$, pure propylene oxide and then placed in a mixture propylene oxide and resin, in a ratio of $3: 1$ and 1:1. Next, the cells were immersed in Epon 812 (Serva, Heidelberg, Germany), polymerized at $40^{\circ} \mathrm{C}$ for $24 \mathrm{~h}$ and $60^{\circ} \mathrm{C}$ for the next $24 \mathrm{~h}$. The preparations were cut into ultrathin slices (ultramicrotome EM UC7, Leica Microsystems, Wetzlar, Germany), and additionally contrasted in uranyl acetate and lead citrate (SPI Supplies, West Chester, PA, USA). The analysis of ultramicroscopic changes was performed using a transmission electron microscope TECNAI G2 Spirit BioTwin (FEI Company, Oregon, USA).

Statistical evaluation. The flow cytometry data were analyzed using CellQuest Pro software (Becton Dickinson, San Jose, CA, USA). All data are presented as the mean values \pm standard deviation, calculated from three independent experiments carried out in duplicate or triplicate. Statistical analyses were performed using STATISTICA 10 (StatSoft, Warszawa, Poland). Data were analyzed by one-way analysis of variance followed by Tukey's honestly significant differences multiple range test. A difference with $p<0.05$ was considered statistically significant.

\section{Results}

Cytotoxic effects of bromoalkyl phenytoin derivatives on human leukemia cells. The influence of $\mathrm{PH} 2, \mathrm{PH} 3$ and $\mathrm{PH} 4$, applied at two concentrations of $50 \mu \mathrm{M}$ and $100 \mu \mathrm{M}$, on HL-60 and U937 cells, was determined. As shown in Figures 2-7, the bromoalkyl phenytoin derivatives triggered regulated cell 
A
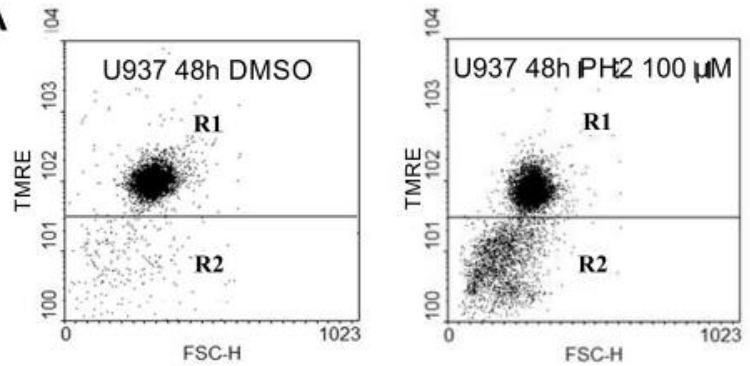

B

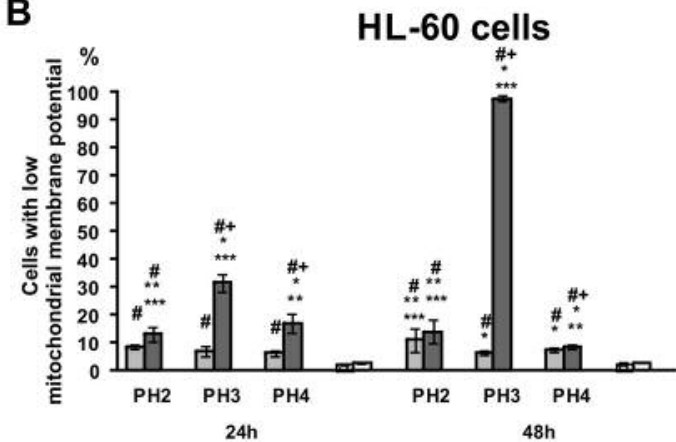

C

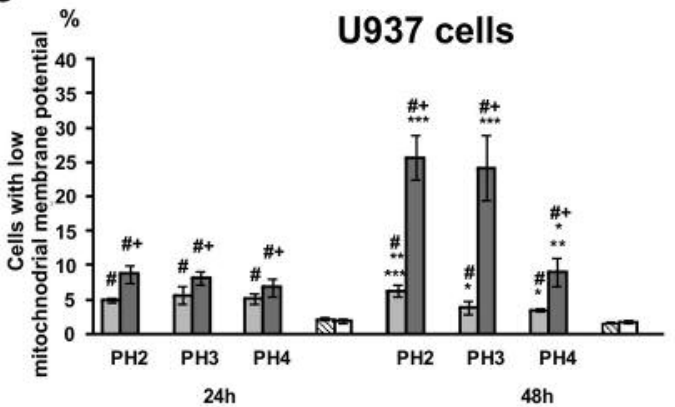

$\mathrm{D} 50 \mu \mathrm{M}$

$\square 100 \mu \mathrm{M}$

DMSO

aControl

$\square 50 \mu \mathrm{M}$

$\square 100 \mu \mathrm{M}$

D DMSO

口Control

Figure 4. Effects of the bromoalkyl phenytoin derivatives, $\mathrm{PH} 2, \mathrm{PH}$, and PH4, on mitochondrial membrane potential of HL-60 and U937 cells. Representative dot plots of U937 cells (A) obtained $48 \mathrm{~h}$ after their exposure to DMSO only, and PH2; R1 - cells with the high mitochondrial membrane potential; $R 2$ - cells with low mitochondrial membrane potential; FL2-H - fluorescence of TMRE, a cell-permeable, positively-charged, red-orange dye which readily accumulates in active mitochondria, and its retention is dependent on mitochondrial membrane potential. The frequency of HL-60 (B) and U937 (C) cells with low mitochondrial membrane potential determined $24 \mathrm{~h}$ and $48 \mathrm{~h}$ after application of $\mathrm{PH} 2, \mathrm{PH} 3$, and $\mathrm{PH} 4$. Values significantly different at $p<0.05$ according to the Tukey's multiple range test: *, **, *** between the groups of leukemia cells exposed to the action of the tested phenytoin analogs; \# compared to controls; + between the time points.

death, affected cell cycle, and caused ultrastructural changes in the human leukemia cells.

Influence of $\mathrm{PH} 2, \mathrm{PH} 3$, and $\mathrm{PH} 4$ on cell death-induction and cell-cycle. Using the flow cytometry assays, the influence of three bromoalkyl derivatives on the frequency of HL-60 and
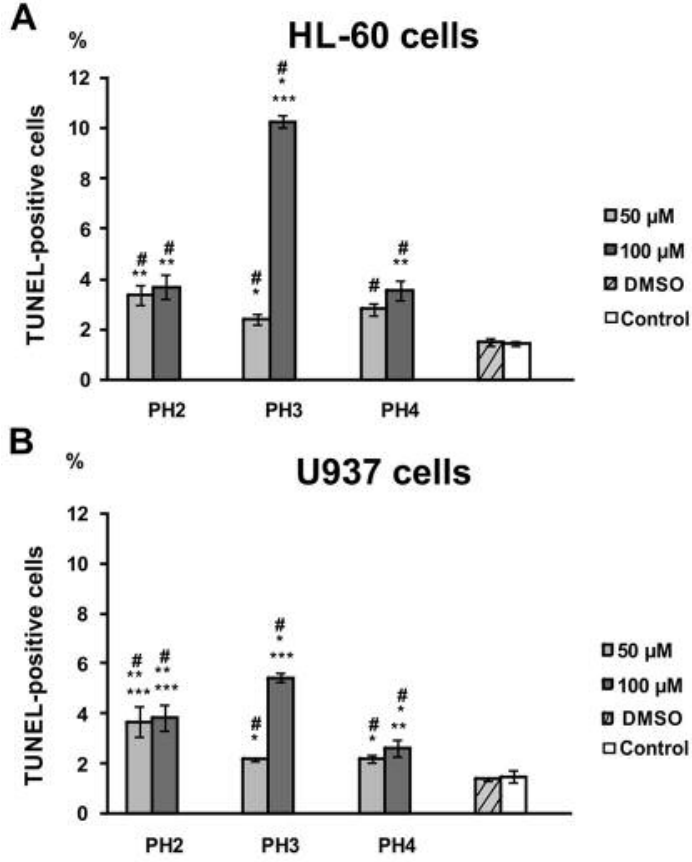

D50 $\mu \mathrm{M}$

$\square 100 \mu \mathrm{M}$

๑ DMSO

口Control

Figure 5. Effects of three bromoalkyl phenytoin derivatives, $\mathrm{PH} 2, \mathrm{PH}$, and PH4, on induction of DNA breakage in HL-60 and U937 cells. The 3'OH termini in the strand breaks was analyzed by attaching FITClabelled Br-dUTP, in a reaction catalyzed by exogenous TdT, and the incorporation of Br-dUTP into DNA strand breaks, detected by FITCconjugated anti-BrdU antibody. The frequency of TUNEL-positive HL-60 (A) and U937 (B) cells observed $24 \mathrm{~h}$ after application of the three tested agents. Values significantly different at $p<0.05$ according to the Tukey's multiple range test: *, **, *** between the groups of leukemia cells treated with the phenytoin analogs, \# compared to controls.

U937 leukemia cells with phosphatidylserine externalization and plasma membrane impairment (Figure 2), the percentage of cells with initiator caspase- 8 and -9 activity and executor caspase-3/7 activity (Figure 3), the frequency of both cells with dissipated mitochondrial membrane potential (Figure 4) and cells displaying DNA fragmentation (Figure 5), and also the percentage of cells in particular phases of the cell cycle (Figure 6 ), was demonstrated. The obtained results were dependent on the 5,5-diphenylhydantoin derivative applied, its concentration, the time intervals after application of the tested agent, and the human leukemia cell line used. In general, among the bromoalkyl phenytoin derivatives, the 3-methyl analog with the bromopropyl chain (PH3) appeared to be the more active in triggering regulated cell death and cell cycle perturbation than the ester- (PH2) and bromobutyl- (PH4) analogs, and HL-60 cells were more sensitive to this action of all tested agents than U937 cells.

Influence of PH2, PH3, and PH4 on human leukemia cell ultrastructure. Using electron microscopy, the ultrastructural 


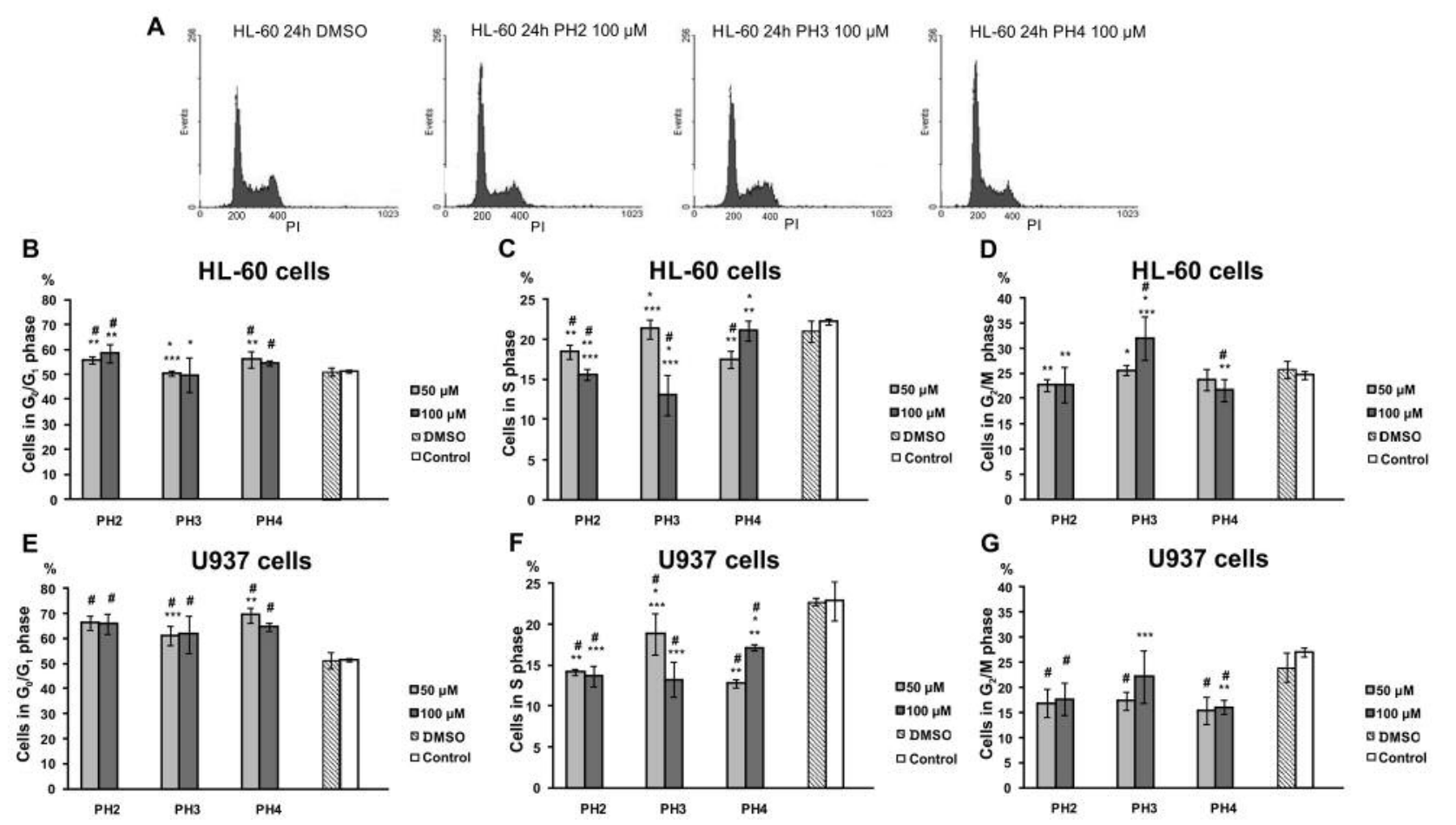

Figure 6. Effects of three bromoalkyl phenytoin derivatives, PH2, PH3 and PH4, on cell-cycle distribution of HL-60 and U937 cells. Representative histograms of the cell cycle of HL-60 cells (A) obtained 24 h after their exposure to the action of DMSO only, PH2, PH3, and PH4; X axis - red fluorescence of PI. The PI/RNase solution was used for staining the total DNA. The frequency of $H L-60(B, C, D)$ and U937 $(E, F, G)$ cells in the particular phases of the cell cycle determined $24 \mathrm{~h}$ after application of the tested agents. Values significantly different at $p<0.05$ according to the Tukey's multiple range test: *,**, *** between the groups of leukemia cells treated with the three phenytoin analogs, \# compared to controls.

changes occurring in HL-60 cells after their exposure to the action of the three bromoalkyl phenytoin analogs, PH2, PH3, and $\mathrm{PH} 4$, were observed (Figure 7). In comparison with the intact ultrastructure of control HL-60 cells, nuclei with slightly widened intermembrane space, slightly swollen endoplasmic reticulum, and a variety of vacuoles were visible after application of the three tested 5,5-diphenylhydantoin derivatives, at the concentration of $50 \mu \mathrm{M}$. Moreover, abnormalities in the Golgi apparatus were found after the exposure of the leukemia cells to the action of PH3 and PH4, at the same concentration. After application of the bromoalkyl phenytoin analogs, at the concentration of $100 \mu \mathrm{M}$, considerable alterations in cell ultrastructure, such as significant swelling of endoplasmic reticulum, the presence of numerous and varied vacuoles in cytoplasm, with different degree of degradation of their content, and formation of vacuoles in intermembrane space of the nucleus, were observed. The action of $\mathrm{PH} 2$ and $\mathrm{PH} 4$ resulted in changes in chromatin distribution in nucleus, distinct matrix condensation in mitochondria. PH4 application caused abnormalities in the Golgi apparatus and lysosomes, and PH3 was responsible for distinct structural disintegration, loss of the plasma membrane integrity, and uncontrolled release of cytoplasmic content into the extracellular space. Thus, the ultrastructural alterations found in the human leukemia HL-60 cells depended on the bromoalkyl phenytoin analog applied, and its concentration.

\section{Discussion}

In the present investigations, the in vitro cytotoxic effects of three bromoalkyl phenytoin derivatives, $\mathrm{PH} 2, \mathrm{PH} 3$, and $\mathrm{PH} 4$ on human promyelocytic leukemia cells and human histiocytic lymphoma cells, were assessed. The results of flow cytometric and electron microscopic analyses demonstrated that these 5,5-diphenylhydantoin derivatives triggered regulated cell death, disturbed the cell cycle, and affected cell ultrastructure. After application of bromoalkyl phenytoin analogs, plasma membrane diversity and impairment, activation of the initiator caspase- 8 and -9 and executor caspase-3/7, dissipation of mitochondrial membrane potential, DNA fragmentation, cell-cycle perturbation, and ultrastructural changes occurring in the nucleus, endoplasmic reticulum, Golgi apparatus, mitochondrium, lysosome, and vacuolar compartments, were found. 

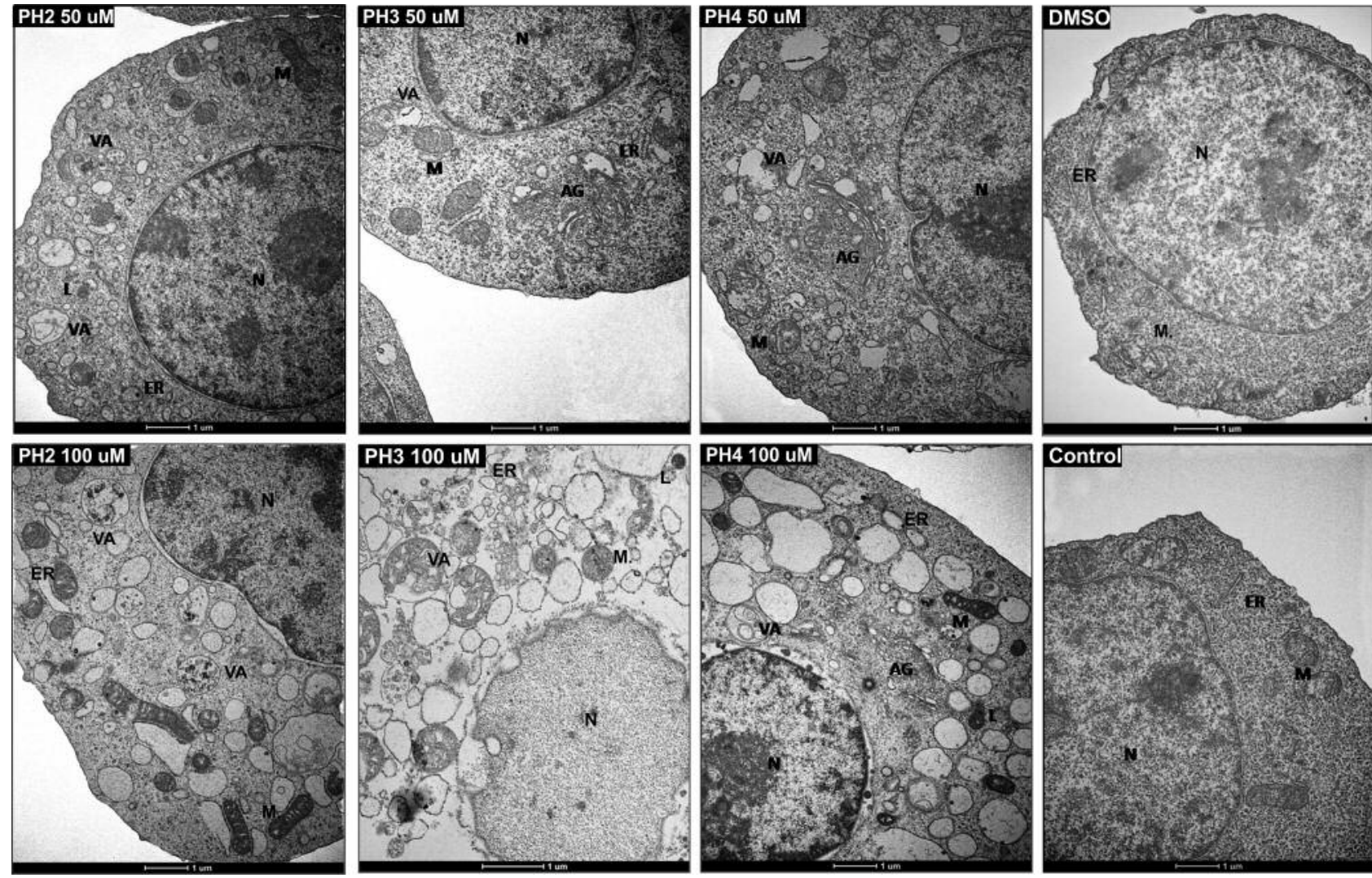

Figure 7. The ultrastructure of HL-60 cells observed 48 h after application of PH2, PH3, and PH4, at the concentration of $50 \mu M$ and $100 \mu M$. Compared to the control cell ultrastructure, changes in the ultrastructure of leukemia cells exposed to the action of the bromoalkyl phenytoin derivatives including chromatin distribution, perinuclear vacuolization, variety of vacuoles in cytoplasm, mitochondrial abnormalities, swelling of endoplasmic reticulum, abnormalities in the Golgi apparatus and lysosomes, and plasma membrane impairment, are visible depending on the agent applied and its concentration. N: Nucleus; M: mitochondria; L: lysosome; ER: endoplasmic reticulum, VA: autophagic vacuole; AG: Golgi apparatus.

It can be generally stated that bromoalkyl phenytoin derivatives triggered apoptosis, necrosis, and autophagy, and in the case of intensive processes of autophagy, cells underwent autophagic death. These tested agents activated caspase- 8 and caspase-9 cascade, respectively, through extrinsic/receptor and intrinsic/mitochondrial pathways, and caused dysfunction of cellular compartments that expressed ultrastructural alterations. Moreover, the 5,5-diphenylhydantoin derivatives distinctly disturbed the cell-cycle phase distribution. These are the first data showing the cytotoxic influence of $\mathrm{PH} 2, \mathrm{PH} 3$, and $\mathrm{PH} 4$ on HL-60 and U937 cells. It should be emphasized that among the tested agents, the bromopropyl analog with 3-methyl substituent (PH3), applied at the concentration of $100 \mu \mathrm{M}$, has the greatest antileukemic activity, and especially against HL-60 cells.

Structural modifications of phenytoin were responsible for the different cytotoxic activities of its bromoalkyl derivatives against HL-60 and U937 cells. The three bromoalkyl phenytoin analogs, $\mathrm{PH} 2, \mathrm{PH} 3$, and $\mathrm{PH} 4$, differ within two substitution places at the hydantoin ring, a substituent at position 3, and the length of the alkyl chain at position 1 of the hydantoin ring. The analog PH2 has the methylpropanoate substituent at position 3, while the compounds $\mathrm{PH} 3$ and $\mathrm{PH} 4$ have only the methyl group. Among the bromoalkyl phenytoin analogs, $\mathrm{PH} 2$ and PH3 have the bromopropyl substituent and PH4 has the bromobutyl one. The presence of bromopropyl or bromobutyl substituent at position 1 of hydantoin ring underlines their alkylating properties (5). Nevertheless, the precise mechanisms of action of the bromoalkyl phenytoin analogs have not yet been completely explained, so further studies are needed.

Little is also known about induction of regulated death and cell-cycle perturbation in pathological hematopoietic cells by other hydantoin derivatives. It was reported that novel derivatives of spirohydantoin caused growth inhibition followed by apoptosis-induction in leukemia cells (11). It was also found that the azaspiro hydantoin derivative triggered apoptosis in human leukemia cells through the mitochondrial pathway following cell cycle arrest (12). 


\section{Conclusion}

The findings of the present study clearly indicate that the bromoalkyl analogs of phenytoin, $\mathrm{PH} 2, \mathrm{PH} 3$, and $\mathrm{PH} 4$, triggered regulated cell death, disturbed cell-cycle distribution, and caused ultrastructural changes in human promyelocytic leukemia cells and human histiocytic lymphoma cells. The antileukemic activity of these three 5,5-diphenylhydantoin derivatives depended on their structural differences at position 1 and 3 as well as on the cell line. The present study provides a new insight into the action of bromoalkyl phenytoin analogs as potential therapeutic agents for pathological hematopoietic cells.

\section{Conflicts of Interest}

The Authors declare that there are no conflicts of interest in regard to this study.

\section{Acknowledgements}

Supported by Research Projects K/DSC/002343 and K/ZDS/004835.

\section{References}

1 Rogawski MA and Löscher W: The neurobiology of antiepileptic drugs. Nature Rev Neurosci 5: 553-564, 2004.

2 Thomas SH and Behr ER: Pharmacological treatment of acquired QT prolongation and torsades de pointes. Br J Clin Pharmacol 81: 420-427, 2016.

3 Handzlik J, Bojarski AJ, Satała G, Kubacka M, Sadek B, Ashoor A, Siwek A, Więcek M, Kucwaj K, Filipek B and KiećKononowicz K: SAR-studies on the importance of aromatic ring topologies in search for selective 5-HT(7) receptor ligands among phenylpiperazine hydantoin derivatives. Eur J Med Chem 78: 324339, 2014.

4 Handzlik J, Bajda M, Zygmunt M, Maciąg D, Dybała M, Bednarski M, Filipek B, Malawska B and Kieć-Kononowicz K: Antiarrhythmic properties of phenylpiperazine derivatives of phenytoin with $\alpha_{1}$-adrenoceptor affinities. Bioorg Med Chem 20: 2290-2303, 2012.

5 Handzlik J, Szymańska E, Chevalier J, Otrębska E, KiećKononowicz K, Pagès JM and Alibert S: Amine-alkyl derivatives of hydantoin: new tool to combat resistant bacteria. Eur J Med Chem 46: 5807-5816, 2011.

6 Matys A, Podlewska S, Witek K, Witek J, Bojarski AJ, Schabikowski J, Otrębska-Machaj E, Latacz G, Szymańska E, Kieć-Kononowicz K, Molnar J, Amaral L and Handzlik J: Imidazolidine-4-one derivatives in the search for novel chemosensitizers of Staphylococcus aureus MRSA: synthesis, biological evaluation and molecular modeling studies. Eur J Med Chem 101: 313-325, 2015.

7 Spengler G, Evaristo M, Handzlik J, Serly J, Molnár J, Viveiros $\mathrm{M}$, Kieć-Kononowicz $\mathrm{K}$ and Amaral L: Biological activity of hydantoin derivatives P-glycoprotein (ABCB1) of mouse lymphoma cells. Anticancer Res 30: 4867-4871, 2010.

8 Spengler G, Handzlik J, Ocsovszki I, Viveiros M, KiećKononowicz K, Molnár J and Amaral L: Modulation of multidrug efflux pump activity by new hydantoin derivatives on colon adenocarcinoma cells without inducing apoptosis. Anticancer Res 31: 3285-3288, 2011.

9 Mahler C: A Review of the Clinical Studies with Nilutamide. In: Antiandrogens in Prostate Cancer. ESO Monographs (European School of Oncology). Denis L. (eds.). Berlin, Heidelberg, Springer, pp. 105-111, 1996.

10 Ananda Kumar CS, Kavitha CV, Vinaya K, Benaka Prasad SB, Thimmegowda NR, Chandrappa S, Raghavan SC and Rangappa KS: Synthesis and in vitro cytotoxic evaluation of novel diazaspiro bicyclo hydantoin derivatives in human leukemia cells: A SAR study. Invest New Drug 27: 327-337, 2009.

11 Kavitha CV, Nambiar M, Ananda Kumar CS, Choudhary B, Muniyappa K, Rangappa KS and Raghavan SC: Novel derivatives of spirohydantoin induce growth inhibition followed by apoptosis in leukemia cells. Biochem Pharmacol 77: 348-363, 2009.

12 Kavitha CV, Nambiar M, Narayanaswamy PB, Thomas E, Rathore U, Ananda Kumar CS, Choudhary B and Rangappa KS: Propyl-2(8-(3,4-difluorobenzyl)-2',5'-dioxo-8-azaspiro[bicyclo[3.2.1] octane-3,4'-imidazolidine]-1'-yl) acetate induces apoptosis in human leukemia cells through mitochondrial pathway following cell cycle arrest. PLoS ONE 8: 1-10, 2013.

13 Śladowska K, Handzlik J, Kieć-Kononowicz K and Mazur L: In vitro cytotoxic activity evaluation of phenytoin derivatives against human leukemia cells. Indian J Exp Biol 54: 553-559, 2016.

14 Galluzzi L, Bravo-San Pedro JM, Vitale I, Aaronson SA, Abrams JM, Adam D, Alnemri ES, Altucci L, Andrews D, AnnicchiaricoPetruzzelli M, Baehrecke EH, Bazan NG, Bertrand MJ, Bianchi K, Blagosklonny MV, Blomgren K, Borner C, Bredesen DE, Brenner C, Campanella M, Candi E, Cecconi F, Chan FK, Chandel NS, Cheng EH, Chipuk JE, Cidlowski JA, Ciechanover A, Dawson TM, Dawson VL, De Laurenzi V, De Maria R, Debatin K-M, Di Daniele N, Dixit VM, Dynlacht BD, El-Deiry WS, Fimia GM, Flavell RA, Fulda S, Garrido C, Gougeon M-L, Green DR, Gronemeyer H, Hajnoczky G, Hardwick JM, Hengartner MO, Ichijo H, Joseph B, Jost PJ, Kaufmann T, Kepp O, Klionsky DJ, Knight RA, Kumar S, Lemasters JJ, Levine B, Linkermann A, Lipton SA, Lockshin RA, López-Otín C, Luglli E, Madeo F, Malorni W, Marine J-C, Martin SJ, Martinou J-C, Medema JP, Meier P, Melino S, Mizuhima N, Moll U, Muñouz-Pinedo C, Nuñez G, Oberst A, Panaretakis T, Penninger JM, Peter ME, Piacentini M, Pinton P, Prehn JH, Puthalakath H, Rabinovich GA, Ravichandran KS, Rizzuto R, Rodrigues CM, Rubinsztein DC, Rudel T, Shi Y, Simon H-U, Stockwell BR, Szabadkai G, Tait SW, Tang HL, Tavernarakis N, Tsujimoto Y, Vanden Berghe T, Vandenabeele P, Villunger A, Wagner EF, Walczak H, White E, Wood WG, Yuan J, Zakeri Z, Zhivotovsy B, Melino G and Kroemer G: Essential versus accessory aspects of cell death: recommendations of the NCCD. Cell Death Differ 22: 58-73, 2015.

15 Mazur L, Augustynek A, Deptała A, Halicka HD and Bedner E: Effects of WR-2721 and cyclophosphamide on the cell cycle phase specificity of apoptosis in mouse bone marrow. Anti-Cancer Drug 13: 751-758, 2002.

16 Marzella L and Glaumann H: Increased degradation in rat liver induced by vinblastine. II. Morphological characterization. Lab Invest 42: 18-27, 1980

Received August 29, 2017

Revised September 21, 2017

Accepted September 22, 2017 